\title{
THE GROWTH OF MICROCOCCUS VARIANS BY UTILIZING SUGAR CANE BLACKSTRAP MOLASSES AS SUBSTRATE
}

\author{
Luís A. S. Miranda; Ernani S. Sant'Anna*; Anna C. S. Porto \\ Departamento de Ciência e Tecnologia de Alimentos, Universidade Federal de Santa Catarina, \\ UFSC/CCA/CAL, Florianópolis, SC, Brasil
}

Submitted: October 15, 1998; Returned to authors for corrections: February 10, 1999; Approved: May 21, 1999

\begin{abstract}
Comparative studies on the growth of Micrococcus varians were carried out in BHI culture medium (control) as well as in a culture medium with $2 \%$ diluted sugar cane blackstrap molasses, enriched with $0.1 \%$ yeast extract. The experiment was conducted with three samples of the experimental and control media in a 5 liter fermentor with working volume of 3.5 liters, continuous agitation $(150 \mathrm{rpm}), 35 \pm 0.1^{\circ} \mathrm{C}$ temperature, $0.7 \mathrm{~L}$ air. $1^{-1}$ medium. $\mathrm{min}^{-1}$, initial $\mathrm{pH} 7.0 \pm 0.2,24$ hour fermentation period, and approximate inoculum of $6.0 \log _{10} \mathrm{CFU} / \mathrm{ml}$. Samples were collected at 2-hour intervals. Micrococcus varians grew in the two culture media studied, which confirms the experimental medium viability for the growth of this species. The final average concentration of biomass was higher in the control medium than in the experimental medium: 0.99 g..$^{-1}$ and 0.78 g..$^{-1}$, respectively. The final number of viable cells at the end of fermentation was $20.65 \log _{10} \mathrm{CFU} / \mathrm{ml}$ for the control medium (BHI), while in the experimental medium the number of viable cells was $19.43 \log _{10} \mathrm{CFU} / \mathrm{ml}$. The consumption of total sugars was higher for the biomass in the control medium (79.78\%), while only $50.53 \%$ was consumed for the experimental medium.
\end{abstract}

Key words: Micrococcus varians, fermentation, molasses

\section{INTRODUCTION}

The practices concerning food fermentation with the purpose of food preservation have been conducted since ancient times (9). Currently, fermented foods are not produced for preservation only, as there are more affordable techniques for that purpose. Now production aims at the development of aromas and flavors which are peculiar to each product, and the development of the technology utilized (3).

Micrococcus varians is a microorganism commonly found in starter culture mixtures utilized in the fermentation of meat products. It is a nonpathogenic microorganism with a nitrate reduction activity, and which is homofermentative, with a scarce production of lactic acid. Among its main characteristics, Micrococcus varians provides a pleasant color and flavor to products (11).

In complex medium such as nutrient agar, Micrococcus varians appears as spherical cells of 0.5 to $2.0 \mu \mathrm{m}$ in diameter, gram positive or gram variable, predominantly arranged in tetrahedrons or diplococcus. The Micrococcus genera morphology

\footnotetext{
* Corresponding author. Mailing address: Departamento de Ciência e Tecnologia de Alimentos - Universidade Federal de Santa Catarina. UFSC/CCA/CAL, Av. Admar Gonzaga, 1346, Itacorubi. CEP 88034-001 Florianópolis, SC, Brazil. E-mail: ernanis@cca.ufsc.br. Fax: (+005548) 331-9943
} 
does not change according to either the culture medium or the age (1).

The processing industry of fermented meat products such as salami utilizes starter cultures due to the various advantages they provide the process with, reducing the losses in the production process and benefiting the product standardization. However, some industries prefer to utilize chemical acidulants such as gluconodelta lactone, but results are not highly satisfactory with regards to flavor (2).

Starter cultures should be approved as GRAS (Generally Recognized as Safety) and laws vary from country to country. However, just a few countries have already regulated the use of microorganisms when processing cured meat. Brazilian laws only establish that the microorganisms utilized for that purpose should be GRAS (7).

In order for a microbial culture to be utilized as a starter culture it should meet some basic requirements, such as: to be salt-tolerant (6 to $10 \%$ brine); to be nitrate-tolerant ( 80 to $100 \mathrm{mg} .1^{-1}$ ); to grow within a range of 26 to $43^{\circ} \mathrm{C}$ and show optimal growing temperature between 32 to $35^{\circ} \mathrm{C}$; to be homofermentative; not to be proteolytic; not to be lipolytic; not to produce flavors and aromas which are atypical to the final product; not to be pathogenic and to present thermal degradation at $57-60^{\circ} \mathrm{C}(12)$. Microbial cultures should not either be toxigenic or produce antibiotics. They should not degrade amino acids into pharmacologically active amines or into sulphidric acid, to produce very little or no hydrogen peroxide, not to produce gas and to produce little or no acetic acid (1).

As in the case of Micrococcus varians, starter cultures are usually traded in their lyophilized form and their production occurs in complex media such as the BHI. This results in a high cost for the final product. In the particular case of Brazil, which has a very strong and developed meat processing industry, starters are imported mainly from Europe and the United States.

Sugar cane molasses is a by-product of the sugar industry, and it is referred to by various names. Among these, blackstrap molasses is the most commonly used name for industrial fermentations.

In Brazil, molasses is the cheapest carbon source, in addition to being a good substrate with respect to vitamin and minerals. Sugar cane molasses is also utilized by the pharmaceutical industry for the production of amino acids and antibiotics and by the additive industry, for the production of flavor intensifiers (5).

This study aims at comparing the growing of Micrococcus varians in sugar cane molasses with those in the BHI, in order to obtain a starter culture with adequate flavor which can be later used as in its frozen form to processing industries.

\section{MATERIALS AND METHODS}

CCT 4492 Micrococcus varians was maintained in BHI broth with $2 \%$ agar in inclined tubes. The culture was incubated at $35^{\circ} \mathrm{C}$ for 24 hours and stored at $4^{\circ} \mathrm{C}$. In order to prevent the medium from drying out, 3 drops of sterile glycerol were added to the culture surface. The sugar cane molasses was collected in aseptic flasks and frozen at $-20^{\circ} \mathrm{C}$. The composition of molasses was determined according to the AOAC methods (15): moisture, ashes, nitrogen, reducing sugar as glucose, non-reducing sugar as sucrose, potassium by flame photometric, magnesium and manganese by atomic absorption, phosphorus by spectrophotometry.

The molasses was diluted with distilled water at $50 \%$ and centrifuged at $4000 \mathrm{rpm}$ for 25 minutes for removal of insoluble solids. The $\mathrm{pH}$ was corrected with $\mathrm{NaOH} 20 \mathrm{M}$ up to $7.0 \pm 0.2 \mathrm{pH}$. The ideal molasses dilution for this experiment was determined through preliminary tests with a dilution rate varying from 1 to $10 \%$. The best Micrococcus varians growth was observed in the medium containing a $2 \%$ molasses dilution.

The inoculum was obtained from a cell removed from the maintenance medium, resuspended in 100 $\mathrm{ml}$ of BHI broth and incubated at $35^{\circ} \mathrm{C}$ for 24 hours. Three $\mathrm{ml}$ aliquots were placed in sterile flasks to which a sterile glycerol at $2 \%$ was added and stored at $-20^{\circ} \mathrm{C}$. Before each fermentation, an inoculum aliquot was adapted to the proposed culture medium by determining the final concentration by spectrophotometry (8) and the cells viability through a plate counting utilizing $\mathrm{BHI}$ agar. A $12 \log _{10} \mathrm{CFU} / \mathrm{ml}$ counting was observed.

The inoculum was diluted $(1: 10)$ with a saline solution with an approximate concentration of up to $6 \log _{10} \mathrm{CFU} / \mathrm{ml}$. A high concentration of microorganisms in the inoculum provides for a fast exhaustion of the substrate, resulting in a nonrecommended reduced exponential phase which damages the production of viable cells.

The experimental medium was constituted of sugar cane molasses diluted at $2.0 \%$ and added by 
$0.1 \%$ of yeast extract $(\mathrm{w} / \mathrm{v})$. The experiments were conducted in batches, in a New Brunswick Scientific fermentor, Bioflo 2000 model, and were repeated 3 times. A BHI broth was utilized as a control medium. The culture was carried out in the following conditions: 3.5 liter medium; $6.0 \log _{10} \mathrm{CFU} / \mathrm{ml}$ inoculum; $150 \mathrm{rpm}$ agitation; $35 \pm 0.1^{\circ} \mathrm{C}$ temperature; 0.71 air..$^{-1}$ medium. $\mathrm{min}^{-1}$ and 24 -hour culture period (fermentation).

Samples were aseptically collected in triplicate, at 2-hour intervals for the evaluation of dry weight and $\mathrm{pH}$ and for determining total sugars. For determining biomass, $2 \mathrm{ml}$ sample aliquots were collected and centrifuged at $4000 \mathrm{rpm}$ for 15 minutes, discarding the supernatant. Three $\mathrm{ml}$ of peptone water at $0.1 \%, 3 \mathrm{ml}$ of EDTA $1 \%$ and two drops of $\mathrm{NaOH}$ $20 \mathrm{M}$ (8) were added to the precipitated. For an evaluation of the growth of viable cells, standard plate counting with BHI agar was utilized (14), incubated at $35^{\circ} \mathrm{C}$ for 24 hours. The biomass was estimated by a spectrophotometric reading at $520 \mathrm{~nm}$, (8). Five $\mathrm{ml}$ aliquots were utilized for determining dry weight and centrifuged at $4000 \mathrm{rpm}$ for 15 minutes. The $\mathrm{pH}$ was monitored during fermentation, at each sample collection. The consumption of sugars was determined by Clegg-Anthrone method (10).

Data were analyzed by analyses of variance. Comparison of treatment means was done using the Tukey's test. A p $<0.05$ was considered be significant.

\section{RESULTS AND DISCUSSION}

The sugar cane molasses utilized in this experiment presented the following composition ( $\mathrm{w} /$ w): moisture $9.10 \mathrm{~g} \%$; ashes $9.98 \mathrm{~g} \%$; total nitrogen $0.52 \mathrm{~g} \%$; reducing sugar as glucose $14.72 \mathrm{~g} \%$; nonreducing sugar as sucrose $33.78 \mathrm{~g} \%$.

Few strains of Micrococcus varians have specific requirements regarding amino acids and vitamins. Several amino acids may apparently meet the needs of organic nitrogen. However, certain specific strains need methionine. The vitamin requirements for this species include thiamin, niacin and pantothenic acid. These characteristics may explain the good performance of the experimental medium utilized (4).

The consumption of total sugars (TS) was higher in the control medium (BHI) (Fig. 1). In this medium, the average TS consumption was $78.79 \%$, which corresponds to a 2.9 g..$^{-1}$ consumption, while in the experimental medium it was $51.53 \%$ and corresponded to an average consumption of 6.18 g. $1^{-1}$, during the 24-hour fermentation period. The highest TS average consumption was $2.56 \mathrm{~g} . \mathrm{l}^{-1}$ $(69.5 \%)$ and it occurred between the 4th and 10th hour-culture in BHI broth. Within the same period the average consumption of sugar in the experimental medium was 2.44 g.l-1 $(19.95 \%)$. The difference in the consumption of substrate between the fermentation of one medium and the other should be attributed to the media composition and to the manner sugars are biologically available in the two media. In the BHI broth as well as in the experimental medium residual sugar may be attributed to the presence of sugars which are not fermented by Micrococcus varians. The high level of residual sugar in the experimental medium (6.05 g. $\left.^{-1}\right)$ may also be attributed to nutritional deficiencies.

The peak consumption observed in Fig. 1, at 4 to 10 -hour interval, partially differs from the exponential phase of microorganisms growth, as shown in Fig. 2. The initial exponential growth occurred at the interval between 4 to 24 hours for the BHI broth, while in the experimental medium it coincided with the 4 to 10 -hour fermentation interval.

The spectrophotometric supervision of cellular growth during fermentation provides an idea of bacterial growth and guidance regarding possible decisions to be made during the experiment. It should be emphasized that the culture is in its stationary

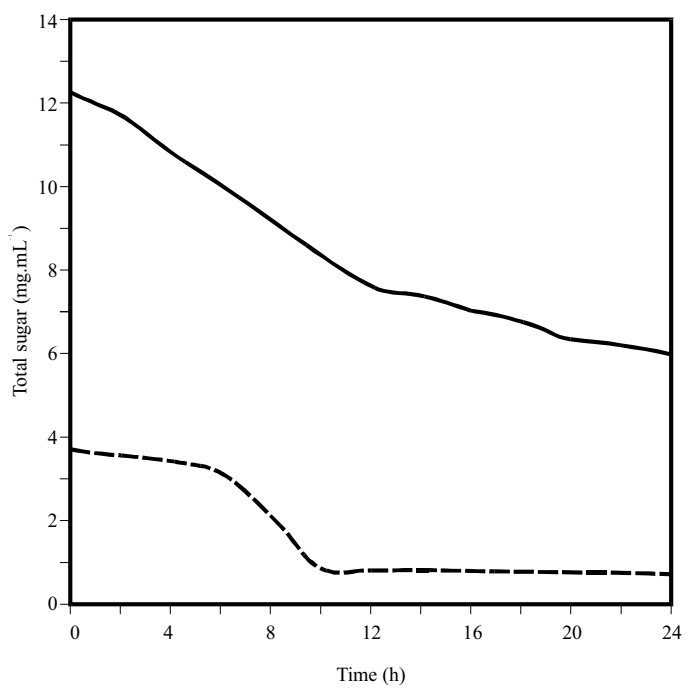

Figure 1 - Consumption of total sugar available for a Micrococcus varians culture in BHI broth (- - ) and sugar cane molasses at 2\% enriched with $0.1 \%$ yeast extract $(-)$. 
phase or is starting the declining phase by the end of the fermentation periods. From this stage onwards, spectrophotometric readings give us a false-positive result given that the optic density tends to increase due to an accumulation of suspended cells and not due to bacterial growth. In order to avoid this type of error, a viable cell counting (Fig. 3) was conducted because the greatest interest in developing a starter culture is to obtain the highest number of viable cells possible.

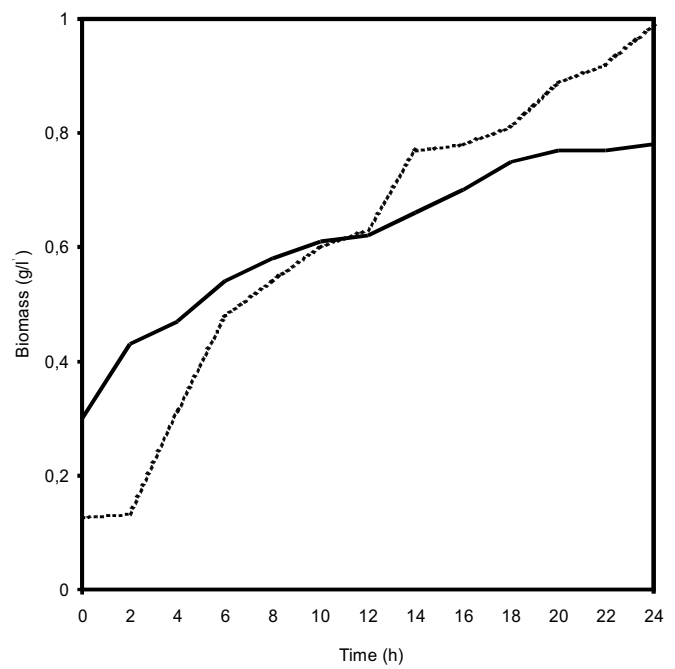

Figure 2 - Micrococcus varians biomass concentration in BHI broth (- - ) and sugar cane molasses at $2 \%$ enriched with $0.1 \%$ yeast extract $(-)$.

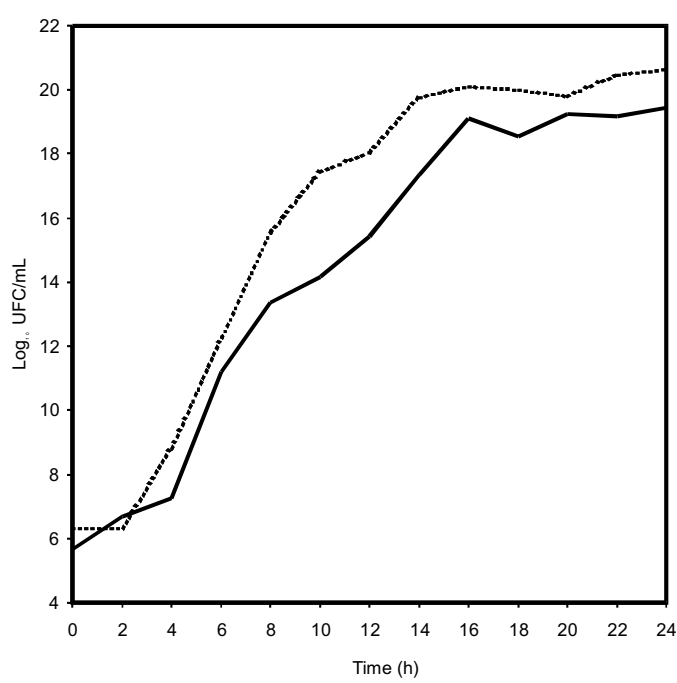

Figure 3 - Viable cells number of Micrococcus varians in BHI broth (- - -) and sugar cane molasses at $2 \%$ enriched with $0.1 \%$ yeast extract (-).
The control medium presented a higher concentration of viable cells $\left(20.65 \log _{10} \mathrm{CFU} / \mathrm{ml}\right)$ than the experimental medium (19.43 $\left.\log _{10} \mathrm{CFU} / \mathrm{ml}\right)$. The difference between the results obtained in the control medium and the experimental medium has also occurred probably due to nutritional deficiencies in the experimental medium. However, the sugar cane molasses enriched with yeast extract presented a good growth level which can be attributed to the composition of the yeast extract in which B vitamins are present and act as bacterial stimulants.

The $\mathrm{pH}$ values remained within a range close to initial $\mathrm{pH}(7.0 \pm 0.2)$, which confirms the Micrococcus varians characteristic of being a nonacidifier microorganism (6). Small variations may be attributed to the production of both primary and secondary metabolites during the fermentation period, in an interaction with the culture's physicochemical conditions.

The highest final biomass concentration was obtained in the control medium fermentation (BHI), $0.99 \mathrm{~g} . \mathrm{l}^{-1}$, while a final concentration of $0.78 \mathrm{~g} . \mathrm{l}^{-1}$ was obtained for the experimental medium, as shown in Fig. 2. Considering that $2 \%$ of sugar cane molasses correspond to $0.97{\mathrm{~g} . \mathrm{l}^{-1}}^{-1}$ of total sugars, we may affirm that $80 \%$ of TS was utilized for biomass production in the experimental medium as it was the main carbon source for the medium. In the control medium (BHI), it is difficult to relate the sugar concentration (glucose) with the biomass produced by the great amount of other carbon sources available (peptone proteases).

The highest biomass productivity was obtained in BHI broth, $0.1178 \mathrm{~g} .1^{-1} \cdot \mathrm{h}(\mathrm{p}<0.05)$, against 0.02 g. $1^{-1} . h$ obtained in experimental medium.

This experiment sought to quantify $\mathrm{N}, \mathrm{Mn}, \mathrm{Mg}$, $\mathrm{P}$ and $\mathrm{K}$ both in the BHI medium and in the experimental medium at the beginning and at the end of the fermentation process with the purpose of detecting nutritional deficiencies in the experimental medium. Results are shown on Table 1.

The consume of the nitrogen total was $1.03 \mathrm{~g} . \mathrm{l}^{-1}$ in BHI medium, while only $0.027{\mathrm{~g} . \mathrm{l}^{-1}}$ were consumed in the experimental medium. The mineral consumption was very clear in the BHI medium with a consumption of $45.13 ; 17.04 ; 50.00$; e $10.97 \%$ of $\mathrm{Mn}, \mathrm{Mg}, \mathrm{P}$ and $\mathrm{K}$ consumed respectively. $\mathrm{Mn}$ and $\mathrm{Mg}$ were the only minerals which showed sensitivity to the techniques utilized in the experimental medium, resulting in a reduction of 37.37 and $41.98 \%$ of these minerals respectively. In regards to $\mathrm{P}$ and $\mathrm{K}$ in the experimental medium, they were both 
Table 1 - Determination of N, Mn, Mg, P and K levels, for Micrococcus varians culture in BHI broth and in sugar cane molasses at $2 \%$, enriched with $0.1 \%$ yeast extract.

\begin{tabular}{|c|c|c|c|c|}
\hline \multirow[t]{2}{*}{ Mineral } & \multicolumn{2}{|c|}{$\mathrm{BHI}$} & \multicolumn{2}{|c|}{ Molasses } \\
\hline & Initial $^{\mathrm{a}}$ & Final $^{b}$ & Initial $^{\mathrm{a}}$ & Final $^{b}$ \\
\hline $\mathrm{N}\left(\mathrm{g} . \mathrm{l}^{-1}\right)$ & 1.1191 & 0.0846 & 0.0734 & 0.0464 \\
\hline $\operatorname{Mn}\left(\mathrm{mg} \cdot \mathrm{l}^{-1}\right)$ & 0.667 & 0.366 & 0.289 & 0.181 \\
\hline $\operatorname{Mg}\left(m g . l^{-1}\right)$ & 110.500 & 91.666 & 0.131 & 0.076 \\
\hline $\mathrm{P}(\%)$ & 0.008 & 0.004 & 0.231 & 0.231 \\
\hline $\mathrm{K}(\%)$ & 0.082 & 0.073 & 0.231 & 0.231 \\
\hline
\end{tabular}

${ }^{a}$ Beginning of fermentation (initial time)

${ }^{\mathrm{b}}$ End of fermentation (24 hours)

quantified at the beginning of the fermentation ( 0.231 and 0.230 respectively) but only traces of these minerals were found at the end of the process. This means that both minerals were almost entirely consumed.

\section{RESUMO}

\section{Crescimento de Micrococcus varians em substrato de melaço de cana-de-açúcar}

Foram realizados estudos comparativos do crescimento de Micrococcus varians em meio de cultura BHI (controle) e em meio constituído de melaço de cana-de-açúcar diluído a $2 \%$ enriquecido com $0,1 \%$ de extrato de levedura. $\mathrm{O}$ experimento foi conduzido com três repetições do meio experimental e controle, em fermentador de 5 litros, com volume de trabalho de 3,5 litros, sob agitação contínua (150 $\mathrm{rpm})$, temperatura de $35^{\circ} \pm 0,1^{\circ} \mathrm{C}$, aeração $0,7 \mathrm{~L}$ ar. $1^{-1}$ meio. $\min ^{-1}, \mathrm{pH}$ inicial 7,0 $\pm 0,2$, tempo de fermentação de 24 horas e inóculo inicial em torno de $\log _{10} \mathrm{UFC} / \mathrm{ml}$. As amostras foram coletadas em intervalos de duas horas. Micrococcus varians cresceu nos dois meios de cultura estudados, confirmando a viabilidade do meio experimental pra o cultivo desta espécie. A concentração média final da biomassa foi maior no meio controle do que no experimental, com 0,99 g..$^{-1}$ e 0,78 g. $1^{-1}$ respectivamente. $\mathrm{O}$ número de células viáveis ao final das fermentações foi de $20,65 \log _{10} \mathrm{UFC} / \mathrm{ml}$ para o BHI (controle) e $19,43 \log _{10} \mathrm{UFC} / \mathrm{ml}$ para o meio experimental. $\mathrm{O}$ consumo de açúcares totais no meio controle foi de $79,78 \%$, enquanto no meio experimental foi de apenas $50,53 \%$.
Palavras-chave: Micrococcus varians, fermentação, melaço.

\section{REFERENCES}

1. Bücke, F.K.; Hecheimann, A. Cultivos starter para embutido seco y jamón crudo: composición y efecto. Fleischwirtschaft, 1: 38-48, 1988.

2. Coventry, J.M.; Hichey, W.M. The effects of spices and manganese on meat starter culture activity. Meat Sci., 33: 391-399, 1993.

3. Erichsen, I. Fermented fish and meat products. In: Roberts, T.A.; Skiner, F.A. (eds.). Food microbiology: advances and prospects, Academic Press, London, 1983.

4. Farrior, J.W.; Kloos, W. Aminoacid and vitamin requeriments of micrococcus species isolated from human skin. Intern. J. System. Bacteriol., 25: 80-82, 1975.

5. Garcia, L.M.; Selgas, D.M.; Fernandez, M.; Ordoñez, J.A. Microorganisms and lipolysis in the rippening of dry fermented sausage. Intern. J. Food Sci. Technol., 27: 675682, 1992

6. Houle, J.F.; Lafrance, M.; Julien, J. P.; Brochu, E.; Champagne, C.P. Selection of mixed cultures for meat fermentation. J. Food Sci., 54: 839-842, 1989.

7. Jessen, B. Starters cultures for meat fermentations. In: Fermented Meats. 1995, p.131-159.

8. Kanasaki, M.; Breheny, S.; Hillier, A.J.; Jago, G.R. Effect of temperature on the growth and acid production of lactic acid bacteria. Austr. J. Food Protect., p.142-144, 1975.

9. Liepe, H.U. Starter cultures in meat production. Biotechnology, v. 5, 1983, p.400-424.

10. Novoa, M.A.O.; Palacios, C.A.M.; León, E.R.M. In: Manual de técnicas para laboratório de nutricion de peces y crustaceos. FAO, México, 1993. p.33-35.

11. Nychas, G.J.E.; Arkoudelos, J.S. Staphylococci the role in fermentaton sausage. J. Appl. Bacteriol., p. 167S-188S, 1990.

12. Smith, J.L; Palumbo, S.A. Use of starter culture in meats. $J$. Food Protect., 46(11): 997-1006, 1983.

13. Talon, R.; Montel, M.C.; Gandemer, G. et alii. Lipolysis of pork fat by Staphylococcus warneri, Staphylococcus saprophyticus and Micrococcus varians. Appl. Microbiol. Biotechnol., 38: 606-609, 1993.

14. Torriani, S.; Dellaglio, R.; Di Bucchianico, R. et alii. Use the selected starter cultures in the of traditional abruzzo salami. Italian J. Food Sci.,7(2): 113-123, 1995.

15. Williams S. (ed.). Official Methods of Analysis of Association of Official Analytical Chemists, $14^{\text {th }}$ ed. A.O.A.C., Arlington, 1984, 1141p. 